\title{
PENGARUH PROFITABILITAS TERHADAP KEBIJAKAN DIVIDEN \\ DAN NILAI PERUSAHAAN \\ Studi Kasus pada Pasar Modal Syariah
}

\author{
Sutrisno \\ Sutrisno_uii@yahoo.com
}

\section{Penulis}

Sutrisno adalah Dosen pada Program Studi Manajemen Fakultas Ekonomi Universitas Islam Indonesia

\section{Abstract}

The purpose of this study is to examine the effect of profitability on dividend policy and firm value. Dividend policy is proxied by the dividend per share, while profitability is proxied by return on equity, return on assets and net profit margin. Firm value measured by price-to-book value ratio. We use firm size as a controlle varable. The population in this study are the companies that are members of the Jakarta Islamic Index (JII). Therefore there are only 30 companies that listed in JII, then all of companies were taken as samples with a four-year observation period (2008-2011). To analyze the data, we use multiple regression that supported by eviews program.The results showed that first profitability variables that significantly affect dividend policy is the return on assets and return on equity, while net profit margin and firm size does not affect the dividend policy. Second, dividend policies significantly affect the firm value. While profitability variables that significantly affect the firm value is the return on equity and return on assets, but net profit margin and firm size does not affect to firm value.

\section{Kata Kunci}

Kebijakan Deviden, Profitabilitas,Nilai Perusahaan, Dividend per-share 


\section{PENDAHULUAN}

Tujuan utama perusahaan bukanlah mencari laba yang maksimum, melainkan berupaya untuk bisa memaksimumkan nilai perusahaan. Herawati (2012) mengungkapkan bahwa memaksimumkan nilai pemegang saham dapat ditempuh dengan cara memaksimalkan nilai sekarang atau present value semua keuntungan pemegang saham yang diharapkan dapat diperoleh dimasa depan. Damodaran (1997:3) juga menegaskan bahwa tujuan perusahaan adalah memaksimumkan nilai perusahaan yang meliputi (1) bagaimana mengalokasikan sumberdaya yang terbatas pada penggunaan yang efektif, (2) bagaimana bisa meningkatkan dana untuk membiayai suatu proyek, dan (3) seberapa besar laba yang diperoleh akan direinvestasikan. Nilai perusahaan bisa diukur dengan berbagai variabel yang salah satunya adalah harga saham. Jika harga saham di pasar mengalami kenaikan, bisa dikatakan bahwa nilai perusahaan semakin meningkat karena kesejahteraan para pemegang saham akan juga semakin meningkat seiring dengan peningkatan harga saham.

Peningkatan harga saham dipengaruhi oleh faktor eksternal perusahaan atau sering disebut faktor teknikal dan bisa disebabkan oleh faktor internal atau faktor fundamental. Kinerja keuangan perusahaan merupakan faktor fundamental yang bisa mempengaruhi para investor untuk melakukan transaksi jual beli saham. Perusahaan yang mempunyai kinerja keuangan bagus akan lebih disukai oleh investor, karena mereka mempunyai harapan investasinya akan aman dan menguntungkan. Kinerja keuangan yang sangat diperhatikan adalah tingkat profitabilitas perusahaan. Dengan tingkat profitabilitas yang tinggi, akan mendorong investor membeli saham perusahaan yang akhirnya dengan semakin 
banyaknya permintaan akan saham perusahaan tersebut akan mendorong harga saham semakin meningkat.

Dalam melakukan investasi pada saham, investor mengharapkan beberapa keuntungan, pertama mengharapkan keuntungan berupa dividen dan kedua mengharapkan keuntungan dari penjualan sahamnya atau capital gain. Oleh karena itu, investor akan lebih menyukai perusahaan-perusahaan yang membagikan dividen. Perusahaan yang membagikan dividen juga bisa dimaksudkan untuk memberikan tanda atau signal kepada investor bahwa perusahaan tersebut dalam kondisi yang sangat baik. Oleh karena itu dengan semakin besarnya dividen yang dibagikan kepada pemegang saham akan semakin meningkatkan kepercayaan investor terhadap perusahaan sehingga sahamnya semakin banyak dicari oleh investor. Jika saham tersebut semakin dicari investor, akan menyebabkan harga saham semakin meningkat dan nilai perusahaan juga akan maksimal. Oleh karena itu manajer keuangan dituntut untuk mengambil kebijakan dividen yang dapat menyeimbangkan kepentingan investor dengan kepentingan perusahaan dalam rangka pengembangan usaha.

\section{KAJIAN TEORI}

\section{Nilai Perusahaan}

Tujuan utama perusahaan yang telah go public adalah meningkatkan kemakmuran pemilik atau para pemegang saham melalui peningkatan nilai keperusahaan. Nilai perusahaan sangat penting karena mencerminkan kinerja perusahaan yang dapat memengaruhi persepsi investor terhadap perusahaan. Nilai perusahaan sering dikaitkan dengan harga saham, dimana semakin tinggi harga saham maka nilai perusahaan dan kemakmuran para pemegang saham pun juga meningkat. Van Horn (2002) mengungkapkan bahwa tujuan perusahaan adalah menciptakan nilai bagi 
pemegang saham atau mensejahterakan para pemilik, dan nilai perusahaan tersebut direpresentasikan dengan harga pasar saham biasa dari perusahaan. Untuk mengukur besarnya nilai perusahaan, bisa digunakan beberapa indikator. Van Horn (2002) yang diperkuat Husnan dan Pudjiastuti (2004) menyatakan bahwa nilai perusahaan bisa diukur dengan price to book value ratio, yaitu perbandingan antara harga per lembar saham dengan nilai buku saham perlembar

\section{Profitabilitas}

Seringkali untuk mengukur kinerja keuangan perusahaan digunakan indikator profitabilitas. Profitabilitas merupakan kemampuan perusahaan dalam menghasilkan laba. Dalam beroperasi untuk menghasilkan laba tersebut perusahaan menggunakan sumber dana baik sumber dana internal yakni dari modal pemilik dan laba ditahan maupun dari eksternal yakni sumber dana yang berasal dari pinjaman pihak lain (Sutrisno, 2010). Kemampuan perusahaan dalam menghasilkan laba dengan semua aset yang dipunyai disebut sebagai return on assets (ROA), sedangkan kemampuan perusahaan dalam menghasilkan laba dengan modal sendiri disebut sebagai return on equity (ROE). Profitabilitas bisa juga diukur dengan net profit margin yakni kemampuan menghasilkan laba dengan hasil penjualan/penghasilan.

Semakin tinggi profitabilitas perusahaan menunjukkan semakin tinggi kemampuan perusahaan dalam menghasilkan laba, yang bisa berdampak terhadap kepercayaan investor terhadap perusahaan. Kondisi ini diharapkan akan mampu menaikan harga saham yang akhirnya akan menaikkan nilai perusahaan. 


\section{Kebijakan Dividen}

Kebijakan dividen merupakan keputusan perusahaan mengenai berapa dividen kas yang harus dibayarkan. Kebijkan dividen ini sangat penting karena dividen ini merupakan pendapatan yang diharapkan oleh investor. Besarnya dividen yang dibayarkan akan mempengaruhi investor apakah akan mempertahankan sahamnya atau akan menjualnya. Kebijakan dividen menjadi masalah yang sangat menarik dalam bidang keuangan semenjak dilontarkannya isu dividen oleh Lintner (1956), dilanjutkan dengan teori yang diajukan oleh Modigliani and Miller (1961) dengan teori dividen tidak relevan. Selanjutnya diteruskan oleh beberapa peneliti lainnya.

Dalam artikel penting teori kebijakan dividen yang ditulis Merton Miller dan Franco Modigliani (1961) atau sering disebut MM, dengan irrelevant theorynya mengemukakan bahwa dividen tidak memiliki pengaruh terhadap harga saham perusahaan, sehingga mereka menganggap dividen menjadi tidak relevan.

Mereka beralasan bahwa nilai perusahaan ditentukan oleh tingkat kemampuan laba dan risikonya, oleh karena itu nilai perusahaan tergantung pada kebijakan investasi aset dibanding bagaimana membagi laba untuk dividen dan laba ditahan. Sementara itu Lintner (1956) berpendapat bahwa kentungan yang disyaratkan akan meningkat sebagai akibat penurunan pembayaran deviden. Investor lebih merasa aman untuk memperoleh pendapatan berupa pembayaran deviden daripada menunggu capital gain. Pendapat Lintner (1956) ini sering disebut sebagai teori bird in the hand. 


\section{PENGEMBANGAN HIPOTESIS}

\section{Profitabilitas dan Kebijakan Dividen}

Kebijakan dividen merupakan faktor yang penting dalam manajemen keuangan, karena kebijakan dividen yang diambil akan bisa memengaruhi nilai perusahaan. Menurut Lintner (1958) manajer lebih menaruh perhatian pada perubahan dividend per share yang sekarang dibanding dengan dividend payout ratio yang tepat, sementara Fama dan Babiak (1968) menegaskan bahwa manajer dalam benaknya mempunyai target dividend payout ratio dan pembayaran DPR dikaitkan dengan proyeksi laba yang akan datang. Pembayaran dividen akan lebih lancar jika perusahaan mempunyai kas yang cukup atau berlebih. Pembayaran dividen juga akan lebih besar jika perusahaan mempunyai tingkat keuntungan yang lebih besar. Suharli (2007) dan Darminto (2008) menemukan pengaruh yang positif antara profitabilitas dengan kebijakan dividen. Demikian pula dengan hasil temuan Jannati dan Attina (2011) dan Ariesta (2012) juga menemukan pengaruh yang positif dan signifikan antara profitabilitas dengan kebijakan dividen. Sementara ada peneliti lain yang menemukan hasil berbeda, seperti Marpaung dan Hadianto (2009) dan Sulistyowati, et.al (2010) menemukan pengaruh yang positif tetapi tidak signifikan antara profitabilitas dengan kebijakan dividen. Oleh karena itu hipotesis yang diajukan adalah sebagai berikut:

$H_{1}$ : Profitabilitas mempunyai pengaruh yang positif terhadap kebijakan dividen

Profitabilitas dan Nilai Perusahaan

Dengan tingkat keuntungan atau profitabilitas yang tinggi, manajer mengharapkan akan mampu meningkatkan kesejahteraan para pemegang saham. 
Karena jika keuntungan dibagikan sebagai dividen akan menjadi signal bahwa perusahaan tersebut sedang dalam kondisi yang bagus sehingga mampu meningkatkan harga saham. Harga saham sebagai salah satu indikator nilai perusahaan, sehingga jika harga saham meningkat diharapkan akan semakin meningkatkan nilai perusahaan. Ariesta (2012) menemukan pengaruh yang positif dan signifikan antara profitabilitas dengan nilai perusahaan. Demikian pula dengan Gul, et.al (2012) dan Gill et.al (2010) juga menemukan pengaruh yang positif dan signifikan antara profitabilitas dengan nilai perusahaan. Hasil yang sama juga ditemukan oleh Setiabudi dan Agustia (2012) yang melakukan penelitian pada perusahaan yang terdaftar di Bursa Efek Indonesia dan Amidu (2007) yang melakukan penelitian di Bursa efek Ghana. Sehingga bisa diajukan hipotesis kedua sebagai berikut:

$\mathrm{H}_{2}$ : Profitabilitas mempunyai pengaruh yang positif terhadap nilai perusahaan

\section{Kebijakan dividen dan Nilai Perusahaan}

Kebijakan dividen merupakan keputusan yang berhubungan dengan besarnya dividen per lembar yang dibagikan kepada pemegang saham. Aharony dan Swary (1980) menemukan respon invetor terhadap perubahan dividen. Jika dividen dinaikkan harga saham meningkat, ketika dividen tidak berubah harga saham tidak mengalami perubahan yang signifikan, jika dividen diturunkan harga saham menurun. Dengan demikian kebijakan dividen bisa mempengaruhi nilai perusahaan. Gul et.al (2012) dan Uwuigbe et.al (2012) menemukan pengaruh yang positif dan signifikan antara kebijakan dividen dengan nilai perusahaan. Demikian pula dengan Amidu (2007) juga menemukan pengaruh kebijakan 
dividen yang positif dan signifikan terhadap nilai perusahaan. Namun beberapa peneliti di Indonesia menemukan hal yang berbeda. Mardiyati et.al (2012) dan Herawati menemukan pengaruh yang positif tetapi tidak signifikan antara kebijakan dividen dengan nilai perusahaan. Demikian pula dengan Ariesta (2012) juga menemukan pengaruh yang tidak signifikan antara kebijakan dividen dengan nilai perusahaan. Dari beberapa kajian dan hasil penelitian tersebut diajukan hipotesis ketiga sebagai berikut:

$H_{3}$ : Kebijakan dividen mempunyai pengaruh yang positif dengan nilai perusahaan

\section{METODE PENELITIAN}

\section{Populasi dan Sampel}

Populasi dalam penelitian ini adalah perusahaan yang ada di Bursa Efek Indonesia (BEI) dan terdaftar pada Jakarta Islamic Index (JII). Karena dalam JII terdapat 30 perusahaan, maka semua perusahaan yang terdaftar dalam JII diambil sebagai sampel. Periode pengambilan sampel selama 4 tahu sejak tahun 2008 sampai dengan tahun 2011.

\section{Variabel Penelitian}

Variabel penelitian ini terdiri dari tiga yakni variabel dependen, variabel independen dan variabel kontrol. Variabel dependen dalam penelitian ini ada dua yakni kebijakan dividen dan nilai perusahaan, sementara variabel independennya profitabilitas dan kebijakan dividen. Profitabilitas di-proxy-kan dengan tiga variabel yakni return on assets (ROA), return on equity (ROE) dan net pofit margin (NPM). Sedangkan variabel kontrol dalam penelitian ini adalah ukuran 
perusahaan. Adapun pengukuran dari masing-masing variabel tersebut adalah sebagai berikut:

Tabel 1. Proksi dan Pengukuran Variabel

\begin{tabular}{|c|l|l|l|}
\hline No & \multicolumn{1}{|c|}{ Variabel } & Proksi & \multicolumn{1}{c|}{ Pengukuran } \\
\hline 1 & Nilai Perusahaan & PBVR & Harga saham/Nilai buku perlembar saham \\
\hline 2 & $\begin{array}{l}\text { Dividend Payout } \\
\text { Ratio }\end{array}$ & DPR & Dividen per share/Earning per share \\
\hline 3 & Retrun on Assets & ROA & EBIT/Total Asset \\
\hline 4 & Return on Equity & ROE & Laba Setelah Pajak/Modal sendiri \\
\hline 5 & Net Profit Margin & LEV & Laba Setelah Pajak/Penjualan \\
\hline 6 & Ukuran Perusahaan & SIZE & Logaritma Total Asset \\
\hline
\end{tabular}

\section{Alat Analisis}

Alat analisis yang digunakan dalam penelitian ini adalah model Analisis Regresi Berganda (Multiple Regression Analysis). Analisis regresi berganda ini digunakan dalam rangka untuk mengetahui (1) pengaruh profitabilitas terhadap kebijakan dividen, (2) pengaruh profitabilitas dan kebijakan dividen terhadap nilai perusahaan. Persamaan regresinya adalah sebagai berikut:

$$
\begin{aligned}
& \mathrm{DPR}=\beta_{0}+\beta_{1} \mathrm{ROA}+\beta_{2} \mathrm{ROE}+\beta_{3} \mathrm{NPM}+\beta_{4} \mathrm{SIZE} \\
& \mathrm{PBV}=\beta_{0}+\beta_{1} \mathrm{DPR}+\beta_{2} \mathrm{ROA}+\beta_{3} \mathrm{ROE}+\beta_{4} \mathrm{NPM}+\beta_{5} \mathrm{SIZE}
\end{aligned}
$$

Dimana:

DPR = Dividend payout ratio

PBV = Price to book value ratio

ROA $=$ Return on assets

ROE = Return on equity

NPM $=$ Net profit margin

SIZE = Ukuran perusahaan

\section{HASIL PENELITIAN}

Untuk menguji pengaruh profitabilitas terhadap kebijakan dividen dan nilai perusahaan, maka data yang diperoleh diolah dengan menggunakan bantuan program e-vews yang hasilnya sebagai berikut:

\section{Pengaruh profitabilitas terhadap kebijakan dividen}


Dari hasil pengolahan data seperti terlihat dalam tabel 2 di bawah, menunjukkan bahwa secara simultan profitabilitas mempunyai pengaruh yang positif dan signifikan yang ditunjukkan dengan probabilitas F-statistiknya sebesar 0.000 lebih kecil dibanding tingkat signifikansi yang disyaratkan 0.05. Secara parsial dari variabel profitabilitas menunjukkan return on asset (ROA) mempunyai pengaruh yang positif dan signifikan terhadap kebijakan dividen yang ditunjukkan dengan tingkat probabilitas signifikans 0.000 lebih kecil dibanding dengan tingkat signifikan yang 0.05 . Demikian pula dengan return on equity (ROE) juga menunjukkan pengaruh positif dan signifikan terhadap kebijakan dividen yang ditunjukkan dengan tingkat signifikansinya 0.0382 lebih kecil dibanding dengan tingkat signifikansi yang disyaratkan. Sementara variabel net profit margin (NPM) menunjukkan pengaruh negatif dan tidak signifikan yang ditunjukkan dengan tingkat signifikansinya 0.5307 lebih besar dengan tingkat signifikansi yang disyaratkan. Ukuran perusahaan (SIZE) sebagai variabel kontrol menunjukkan pengaruh yang negatif dan tidak signifikan terhadap kebijakan dividen

Tabel 2

Dependent Variable: Kebijakan Dividen (DPR) Included observations: 120

\begin{tabular}{crlrr}
\hline \hline Variable & Coefficient & Std. Error & t-Statistic & Prob. \\
\hline \hline ROA & 1117.614 & 916.4924 & 1.219447 & 0.2252 \\
ROE & 11.38628 & 0.734618 & 15.49959 & 0.0000 \\
NPM & 2.910236 & 7.757418 & 0.375155 & 0.0382 \\
SIZE & -49.45762 & 55.03398 & -0.898674 & 0.5307 \\
R-squared & -15.34284 & 41.88226 & -0.366333 & 0.7148 \\
Adjusted R-squared & 0.730445 & Mean dependent var & 6915.800 \\
S.E. of regression & 0.718622 & S.D. dependent var & 11730.92 \\
Sum squared resid & 4.412 .670 & Akaike info criterion & 20.35849 \\
Log likelihood & -1215.510 & Schwarz criterion & 20.49787 \\
Durbin-Watson stat & 1.909478 & F-statistic & 61.78386 \\
\hline \hline & Prob(F-statistic) & 0.000000 \\
\hline
\end{tabular}




\section{Pengaruh profitabilitas dan kebijakan dividen terhadap nilai perusahaan}

Tabel 3 di bawah menunjukkan pengaruh profitabilitas dan kebijakan dividen terhadap nilai perusahaan, dimana kebijakan dividen yang diproksikan dengan dividend payout ratio (DPR) mempunyai pengaruh yang positif dan signifikan terhadap nilai perusahaan yang ditunjukkan hasil probabilitas tstatistiknya sebesar 0.0013 lebih kecil dibandingkan dengan tingkat signifikansi yang disyaratkan. Variabel profitabilitas yang secara signifikan mempengaruhi nilai perusahaan adalah return on assets (ROA) dan return on equity (ROE) yang ditunjukkan dengan besarnya nilai signifikansinya lebih kecil dari 0.05 . Sedangkan net profit margin mempunyai pengaruh negatif dan tidak signifikan terdadap nilai perusahaan. Ukuran perusahaan (SIZE) sebagai variabel kontrol juga pengaruhnya tidak signifikan terhadap nilai perusahaan.

Tabel 3

Dependent Variable: Nilai Perusahaan (PBV) Included observations: 120

\begin{tabular}{crllr}
\hline \hline Variable & Coefficient & Std. Error & t-Statistic & Prob. \\
\hline C & 0.690881 & 0.449500 & 1.537000 & 0.1271 \\
DPR & 0.001187 & 0.000360 & 3.295198 & 0.0013 \\
SIZE & 0.004174 & 0.003805 & 1.096994 & 0.2750 \\
ROE & 0.178198 & 0.026992 & 6.601949 & 0.0000 \\
ROA & 0.011759 & 0.048285 & 0.243529 & 0.8080 \\
NPM & -0.101866 & 0.020541 & -4.959067 & 0.0000 \\
\hline \hline R-squared & 0.610666 & Mean dependent var & 3.526750 \\
Adjusted R-squared & 0.593590 & S.D. dependent var & 4.787354 \\
S.E. of regression & 3.051951 & Akaike info criterion & 5.118146 \\
Sum squared resid & 1061.842 & Schwarz criterion & 5.257520 \\
Log likelihood & -301.0887 & F-statistic & 35.76162 \\
Durbin-Watson stat & 1.270173 & Prob(F-statistic) & 0.000000 \\
\hline \hline
\end{tabular}

\section{PEMBAHASAN}

Dari hasil penelitian di atas ditemukan uji $\mathrm{F}$ dari pengaruh profitabilitas terhadap kebijakan dividen sebesar 0.0000 lebih kecil dibanding tingkat signifikansinya 0.05 . Ini menunjukkan secara bersama-sama profitabilitas mempengaruhi kebijakan dividen. Sedangkan secara parsial variabel ROA dan 
ROE mempunyai pengaruh positif dan signifikan terhadap kebijakan dividen, hanya NPM yang pengaruhnya tidak signifikan terhadap kebijakan dividen. Ini menunjukkan bahwa memang profitabilitas mempunyai pengaruh terhadap kebijakan dividen yakni semakin besar profitabiltas perusahaan ada kecenderungan membagikan dividen yang lebih besar. Hasil penelitian ini sejalan dengan beberapa peneliti sebelumnya, seperti Suharli (2007) dan Darminto (2008) yang menemukan pengaruh yang positif dan signifikan antara profitabilitas dengan kebijakan dividen. Demikian pula dengan Jannati (2011) yang meneliti pada perusahaan barang-barang konsumsi juga menemukan hal yang sama. Namun ada beberapa peneliti yang menemukan hal sebaliknya. Marpaung dan hadianto (2009) dan Sulistyowati et.al (2010) menemukan pengaruh yang positif tetapi tidak signifikan.

Sementara pengaruh kebijakan dividen terhadap nilai perusahaan menunjukkan pengaruh yang positif dan signifikan yang ditunjukkan dengan hasil uji t-statistik lebih kecil dari taraf signifikansinya. Hal ini menunjukkan bahwa kebijakan dividen yang meningkat akan meningkatkan harga saham, sebab proksi nilai perusahaan adalah price to book value ratio (PBV) artinya semakin tinggi (PBV) semakin tinggi harga saham. Hasil penelitian ini mendukung temuan beberapa peneliti sebelumnya. Gul et.al (2012), Uwuigbe et.al (2012), dan Amidu (2007) juga menemukan pengaruh yang positif dan signifikan kebijakan dividen terhadap nilai perusahaan. Temuan ini mengindikasikan bahwa perusahaan memanfaatkan labanya lebih banyak digunakan untuk membayar dividen dibanding untuk pengembangan usahanya (sebagai laba ditahan). Namun ada beberapa peneliti yang menemukan hal berbeda seperti Ariesta (2012), Herawati 
(2012), dan Mardiyati et.al (2012) menemukan pengaruh yang tidak signifikan. Ini artinya ada beberapa perusahaan yang menggunakan labanya untuk direinvestasikan lagi.

Sedangkan pengaruh profitabilitas terhadap nilai perusahaan secara simultan menunjukkan pengaruh yang positif dan signifikan yang ditunjukkan dengan f-statistik sebesar 0.000 lebih kecil dibanding taraf signifikansi yang disyaratkan. Sedangkan variabel profitabilitas yang secara positif dan signifikan mempengaruhi nilai perusahaan adalah ROA dan ROE. Kedua variabel ini sama konsisten dengan pengaruhnya terhadap kebijakan dividen. Ini menunjukkan bahwa semakin tinggi profitabilitas akan semakin menyakinkan para pemegang saham dan investor terhadap kinerja perusahaan, sehingga bisa meningkatkan harga saham. Hasil penelitian ini mendukung hasil penelitian Ariesta (2012), Herawati (2012), dan Mardiyati et.al (2012), Setiabudi dan Agustia (2012) yang melakukan penelitian di Bursa Efek Indonesia (BEI). Hasil yang sama juga ditemukan oleh Gill et.al (2010) yang melakukan penelitian di Amerika serikat dan Amidu (2007) yang melakukan penelitian di pasar modal Ghana juga menghasilkan temuan yang sama.

\section{PENUTUP}

Dari hasil analisis dan pembahasan diatas, maka dapat disimpulkan bahwa secara simultan profitabilitas mempengaruhi kebijakan dividen. Secara parsial variabel profitabilitas yang secara signifikan mempengaruhi kebijakan dividen adalah retrun on assets (ROA) dan return on equity (ROE), hanya variabel net profit margin (NPM) yang pengaruhnya tidak signifikan terhadap kebijakan 
dividen. Hal ini sejalan dengan temuan Darminto (2008), Suharli (2007) dan Jannati (2011).

Sementara itu kebijakan dividen juga terbukti positif dan secara signifikan mempengaruhi nilai perusahaan. Hal ini menunjukkan bahwa semakin besar porsi laba yang dibagikan kepada pemegang saham semakin meningkatkan nilai perusahaan. Temuan ini sesuai dengan Ariesta (2012), Gul et.al (2012), Uwuigbe et.al (2012), dan Amidu (2007). Sedangkan variabel profitabilitas yang secara signifikan mempengaruhi nilai perusahaan adalah ROA dan ROE. Hanya NPM yang pengaruhnya tidak signifikan terhadap nilai perusahaan. Pengaruh profitabilitas terhadap nilai perusahaan ini sesuai dengan hasil penelitian Ariesta (2012), Herawati (2012), Gill et.al (2010), dan Mardiyati et.al (2012). Demikian pula dengan penelitian Setiabudi dan Agustia (2012) dan Amidu (2007) juga menemukan hal yang sama.

\section{DAFTAR PUSTAKA}

Aharony, Joseph dan Itsak Swary, 1980, Quarterly Dividend and Earnings Announcements and Stockholders' returns: An Empirical Analysis, Journal of Finance, 35, 1-12

Amidu, Mohammed., 2007, How Does Dividend Policy Affect Performance of The Firm On Ghana Tock Exchange?, Investment Management and Financial Innovations, 4(3), 103-112

Damodaran, Aswad., 1997, Corporate Finance, Theory and Practice, Singapore: John Wiley \& Son, Inc 
Darminto, 2008, Pengaruh Profitabilitas, Likuiditas, Struktur Modal Dan Struktur Kepemilikan Saham, Terhadap Kebijakan Dividen, Jurnal Ilmu-Ilmu Sosial, Vol. 20 - No. 2

Fama, Eugene F., dan Harvey Babiak, 1968, Dividend Policy: An Empirical Analysis, Jorunal of the American Statistical Association, 63. 1132-1161

Gill, Amarjit., Nahum Biger dan Rajendra Tibrewala., 2010, Determinants of Dividend Payout Ratios: Evidence from United States, The Open Business Journal, 3, 8-14

Gul, Sajid., Muhammad Sajid, Nasir Razzaq, Muhammad Farrukh Iqbal, Muhammad Bilal Khan., 2012, “The Relationship between Dividend Policy and Shareholder's Wealth" (Evidence from Pakistan), Economics and Finance Review, Vol. 2(2) pp. 55 - 59

Herawati, Titin., 2012, Pengaruh Kebijakan Dividen, Kebijakan Hutang dan Profitabilitas Terhadap Nilai Perusahaan, Working Paper, Universitas Negeri Padang

Jannati, Attina, 2011, Pengaruh Profitabilitas, Leverage, Dan Growth Terhadap Kebijakan Dividen (Sensus pada Perusahaan Manufaktur Consumer Goods Industry yang listing di Bursa Efek Indonesia), Working Paper, Program Studi Akuntansi Fakultas Ekonomi, Universitas Siliwangi.

Lintner, John., 1956, Distribution of Incomes of Corporation Among Dividends, Retained Earning, and Taxes, American Economic Reviews, 46, 97-113

Mardiyati, Umi., Gatot Nazir Ahmad dan Ria Putri, 2012, Pengaruh Kebijakan Dividen, Kebijakan Hutang Dan Profitabilitas Terhadap Nilai Perusahaan 
Manufaktur Yang Terdaftar Di Bursa Efek Indonesia (BEI) Periode 20052010, Jurnal Riset Manajemen Sains Indonesia (JRMSI), 3(1)

Marpaung, Elyzabet Indrawati dan Bram Hadianto, 2009, Pengaruh Profitabilitas dan Kesempatan Investasi terhadap Kebijakan Dividen: Studi Empirik pada Emiten Pembentuk Indeks LQ45 di Bursa Efek Indonesia, Jurnal Akuntansi, Vol.1 No.1, 70-84

Miller M. H and Modigliani F., 1961, Dividend policy, growth and the valuation of shares, The Journal of Business, Vol. 34, pp. 411-433.

Husnan, Suad., dan Enny Pujiastuti, 2004, Dasar-dasar Manajemen Keuangan, Edisi Keempat, Yogyakarta: UPP AMP YKPN

Suharli, Michell., 2007, Pengaruh Profitability dan Investment Opportunity Set Terhadap Kebijakan Dividen Tunai dengan Likuiditas Sebagai Variabel Penguat (Studi pada Perusahaan yang Terdaftar Di Bursa Efek Jakarta Periode 2002-2003), Jurnal Akuntansi Dan Keuangan, Vol. 9, No. 1, 9-17

Setiabudi, Andy dan Dian Agustia, 2012, Fundamental Factor of Firm due to the Firm Value, Journal of Basic and Applied Scientific Research, 2(12), $12651-12659$

Sulistiyowati, Indah., Ratna Anggraini dan Tri Hesti Utaminingtyas, 2010, Pengaruh Profitabilitas, Leverage, dan Growth Terhadap Kebijakan Dividen dengan Good Corporate Governance sebagai Variabel Intervening, Proceeding: Simposium Nasional Akuntansi

Sutrisno, 2010, Manajemen keuangan: Teori, Konsep dan Aplikasi, Penerbit Ekonisia, Yogyakarta 
Uwuigbe., Uwalomwa, Jimoh Jafaru, Dan Anijesushola Ajayi, 2012, Dividend Policy And Firm Performance: A Study Of Listed Firms In Nigeria, Accounting and Management Information Systems, 11(3), pp. 442-454

Wiyono, Ariesta Aprilycia, 2012, Pengaruh Profitabilitas, Kebijakan Dividen, Dan Kebijakan Utang Terhadap Kinerja Pasar Dengan Moderasi Aliran Kas Bebas, Jurnal Ilmiah Mahasiswa Akuntansi, 19(1)

Van Horne, James C., 2002, Financial Magament and Policy, Twelfth Edition, New Jersey: Prentice Hall International Inc 